\title{
Participation of Nitric Oxide in Different Models of Experimental Hypertension
}

\section{J. TÖRÖK}

Institute of Normal and Pathological Physiology, Slovak Academy of Sciences, Bratislava, Slovakia

Received April 18, 2008

Accepted August 26, 2008

\section{Summary}

This review concerns the role of nitric oxide (NO) in the pathogenesis of different models of experimental hypertension (NO-deficient, genetic, salt-dependent), which are characterized by a wide range of etiology. Although the contribution of NO may vary between different models of hypertension, a unifying characteristic of these models is the presence of oxidative stress that participates in the maintenance of elevated arterial pressure and seems to be a common denominator underlying endothelial dysfunction in various forms of experimental hypertension. Besides the imbalance between the endothelial production of vasorelaxing and vasoconstricting compounds as well as the relative insufficiency of vasodilator systems to compensate augmented vasoconstrictor systems, there were found numerous structural and functional abnormalities in blood vessels and heart of hypertensive animals. The administration of antihypertensive drugs, antioxidants and NO donors is capable to attenuate blood pressure elevation and to improve morphological and functional changes of cardiovascular system in some but not all hypertensive models. The failure to correct spontaneous hypertension by NO donor administration reflects the fact that sympathetic overactivity plays a key role in this form of hypertension, while NO production in spontaneously hypertensive rats might be enhanced to compensate increased blood pressure. A special attention should be paid to the modulation of sympathetic nervous activity in central and peripheral nervous system. These results extend our knowledge on the control of the balance between NO and reactive oxygen species production and are likely to be a basis for the development of new approaches to the therapy of diseases associated with NO deficiency.

\section{Key words}

Endothelium - Nitric oxide - Reactive oxygen species • Endothelial dysfunction - Arterial structural changes - NOdeficient hypertension $\bullet$ Genetic hypertension $\bullet$ Salt hypertension

\section{Corresponding author}

J. Török, Institute of Normal and Pathological Physiology, Slovak Academy of Sciences, Sienkiewiczova 1, Bratislava, 813 71, Slovak Republic. E-mail: Jozef.torok@savba.sk

\section{Introduction}

Vascular tone results from the interactions between the neural and endothelial control mechanisms. At any time, it depends on prevailing conditions which mechanism has more influence. It seems likely that endothelial release of vasoactive substances may be of greater significance for the response of blood vessels to local changes in their environment, such as hypoxia and increased flow. By contrast, perivascular nerves integrate the control of blood flow in the organism as a whole. Long-term disturbances in the balance of interactions between perivascular nerves and endothelial cells may be of significance in the development of cardiovascular diseases (Lincoln and Burnstock 1990).

Two dominant vasoactive systems (endothelium and sympathetic nerves) seem to be well-balanced counterparts of blood pressure regulation in normotensive animals. During experimental conditions using a sequential blockade of renin-angiotensin system (RAS), sympathetic nervous system (SNS) and NO synthase (NOS) Kuneš et al. (2004) revealed a characteristic imbalance between sympathetic activity and relative NO 
deficiency in most of the examined models of experimental hypertension.

The vascular endothelium synthesizes and releases a spectrum of vasoactive substances that modulate vascular tone, homeostasis, inflammatory responses and angiogenesis. The vasoactive factors include relaxing (nitric oxide, prostacycline, adenosine, C-natriuretic peptide, etc.) and contracting factors (thromboxane $\mathrm{A}_{2}$, endothelin-1, angiotensin II, superoxide anion, etc.). In normotensive animals the vasodilating factors are produced in large amounts enabling the endothelium to oppose the vasoconstricting tone generated by the activity of the sympathetic nervous system. Endothelial cells communicate with smooth muscle cells via myoendothelial gap junctions that allow the spread of electrotonic tone (endothelium-derived hyperpolarizing factor, EDHF) (Félétou and Vanhoutte 2006).

Damage to the endothelium upsets the balance between vasoconstriction and vasodilatation and initiates a number of events/processes that promote or exacerbate atherosclerosis; these include increased endothelial permeability, platelet aggregation, leukocyte adhesion, and generation of cytokines (Ross 1999). Endothelial dysfunction, which is characterized by impairment of nitric oxide bioavailability, is an important risk factor for both hypertension and cardiovascular diseases. Moreover, an alteration in the production of prostanoids, an impairment of endothelium-dependent dilatation or/and hyperpolarization, as well as an increased release of endothelin, can individually or altogether contribute to endothelial dysfunction.

Oxidative stress has been suggested to be involved in the pathophysiology of various forms of hypertension (Romero and Reckelhoff 1999) and appears to be a common denominator underlying endothelial dysfunction in cardiovascular diseases. Under normal conditions the endothelial mediator nitric oxide negatively modulates the activity of the adrenergic portion of sympathetic neurotransmission. The increased oxidative stress in pathological conditions contributes to the dysfunction in the NO modulation of sympathetic neurotransmission. Nitric oxide reacts with superoxide $\left(\mathrm{O}^{2-}\right)$ and other reactive oxygen species to produce peroxynitrate, a highly cytotoxic reactive nitrogen species, suggesting that increased production of reactive oxygen species may activate sympathetic nervous system through enhanced oxidation/inactivation of nitric oxide. Because nitric oxide exerts a tonic inhibition of sympathetic nerve system activity (Tseng et al. 1996), a decrease in NO caused by angiotensin II could mediate the increase in sympathetic activity.

In the last two decades a large body of experimental evidence has been accumulated demonstrating that NO released from endothelial cells is a crucial regulator of vascular tone. While the primary endothelium-derived vasodilator autacoid is nitric oxide, it is clear that epoxyeicosatrienoic acid and other endothelium-derived hyperpolarizing factors, as well as endothelin-1 and reactive oxygen species, play a significant role in the regulation of vascular tone and gene expression (Busse and Fleming 2006).

The aim of this short review is to analyze the role of nitric oxide in different models of experimental hypertension.

\section{NO-deficient hypertension}

Endogenous nitric oxide is synthesized in vascular endothelial cells by conversion of L-arginine to L-citrulline by the enzyme NO synthase (Moncada 1992). Commonly used substance to activate endothelial receptors is acetylcholine. But there are several other agents (histamine, bradykinin, ATP, 5-hydroxytryptamin, thrombin, etc.) that produce relaxation of arteries either by direct action on the smooth muscle or by indirect action mediated by activation of endothelial receptors, the indirect action being stronger than the direct one.

High flow-induced shear stress is also an important factor in the NO-dependent regulation of peripheral resistance (Smieško and Johnson 1993). The dilation induced by high blood flow requires the integrity of vascular endothelium since removal of the endothelium in isolated perfused canine femoral arteries in situ abolished the flow-dependent dilatation (Smieško et al. 1985). These results suggest that the endotheliumdependent control of conduit arteries by flow-related shear stress is a significant mechanism of flow regulation at normal flow rates and is critically important during high flow condition. Thus fluid shear stress represents a major stimulus for the continuous production of $\mathrm{NO}$ in vivo, which is a highly effective and sensitive system to counteract myogenic and neurogenically induced vascular contraction.

Endothelium-dependent relaxation of artery, first demonstrated by Furchgott and Zawadski (1980), is dependent on the integrity of the endothelium. Acetylcholine was shown to elicit marked relaxation in 
the thoracic aorta of the dog already before birth. This relaxation was fully operative during whole perinatal period and its extent declined towards adulthood (Török and Gerová 1997). The existence of profound endothelium-dependent relaxation in the dog aorta in perinatal period indicates that enzymatic equipment of endothelial cells required for NO production was fully developed prenatally. This statement was experimentally supported by the finding of a high endothelial constitutive NO synthase mRNA level in the rat during late fetal life (Arnal et al. 1994).

The four-week-lasting in vivo administration of NO synthase inhibitors such as $\mathrm{N}^{\mathrm{G}}$-nitro-L-arginine methyl ester (L-NAME) produces the elevation in arterial blood pressure and an increase in peripheral vascular resistance that is associated with further functional and structural changes (Gardiner et al. 1990, Ribeiro et al. 1992, Bernátová et al. 1999a). Chronic inhibition of NO synthase in adult rats produces endothelial dysfunction, increase of vascular responsiveness to adrenergic stimuli and perivascular inflammation (Török and Gerová 1996, Holécyová et al. 1996, Pecháňová et al. 1999, Hsieh et al. 2004). Several other factors including renin-angiotensin system (Takemoto et al. 1997), endothelial constricting factors (Paulis et al. 2008a), arterial remodeling and sympathetic nervous system (the activity of which is modulated by brain NO availability) (Patel et al. 2001) seem to be involved in L-NAME-induced hypertension. Morphological studies revealed cardiac and vascular hypertrophy, fibrosis and atherosclerosis (Kristek and Gerová 1996a,b, Babál et al. 1997). On the other hand, lower smooth muscle cell volume density, indicating hypotrophy of conduit arteries, was found in rat offspring from parents with sustained NO-deficient hypertension (Kristek and Gerová 2004). Pharmacological modulation of the above systems indicated their important role in the development or maintenance of L-NAME-induced hypertension.

However, deficient NO formation seems to be the principal factor responsible for the development of L-NAME-induced hypertension. Such an idea is also supported by the fact that this type of hypertension can be prevented by NO donor administration. For many decades, nitrovasodilators have been used for the treatment of angina pectoris because of their ability to generate NO (Ahlner et al. 1991). Research to date has focused mainly on the cardiovascular system in which reduced bioavailability of $\mathrm{NO}$ is promising therapeutic option in the treatment of cardiovascular diseases. Novel forms of nitrovasodilators as pentaerythrityl tetranitrate (PETN) and molsidomine represent effective tolerancedevoid NO donors with beneficial pharmacological effect. This consists in protecting effect against blood pressure elevation most probably due to the activation of guanylate cyclase by NO liberated from NO donors. We have found that the inhibitory effect of L-NAME on endothelial function was entirely reversed by the simultaneous treatment of rats with NO donors PETN and/or molsidomine (Kristek 2000, Török and Kristek 2002).

There is a question whether NO synthase inhibitors always act as inhibitors. Recently, Bernátová et al. (2007b) showed that chronic administration of the low doses of L-NAME resulted in a transient elevation of blood pressure only. This was associated with elevation of NOS activity in aorta and left ventricle and was accompanied by enhanced endothelium-dependent relaxation and reduced vasoconstriction of the femoral artery. These findings suggest that chronic administration of low doses of L-NAME could be used to increase NO production in contrast to supplementation with exogenous NO donors, which may inhibit endogenous NO synthesis.

Prolongation of L-NAME administration from 4 to 8 weeks further increased blood pressure, but did not enhance the impairment of endothelium-dependent relaxation (Török et al. 1998). After 4 weeks of L-NAME treatment endothelial NO synthase (eNOS) expression in the heart was significantly increased and this increase was amplified after 7 weeks of treatment (Pecháňová et al. 2008). It seems that the up-regulation of eNOS protein expression represents one of counterregulatory mechanisms activated to compensate the increase of blood pressure. On the other hand, eNOS expression in the brain remained unchanged after 4 weeks of L-NAME treatment and prolongation of the treatment led to a further decrease of eNOS expression in this tissue (Pecháňová et al. 2008). Since blood pressure increase persisted after 7 weeks of L-NAME treatment, they hypothesized that central regulation of blood pressure is predominant in L-NAME-induced hypertension.

NO-deficient hypertension may be reversed either by removing the initiating cause (ceasing of L-NAME administration) (Bernátová et al. 2002) or by administration of various antihypertensive drugs. The treatment of rats with captopril, an inhibitor of angiotensin converting enzyme (ACE), prevented the development of hypertension and left ventricle hypertrophy in L-NAME-treated rats, but did not affect 
NO synthase inhibition (Pecháňová et al. 1997, Bernátová et al. 1999b). This suggests that the reninangiotensin system plays a considerable role in the development of hypertension and cardiac hypertrophy. On the other hand, Zicha et al. (2006a) reported that chronic captopril administration to L-NAME-treated rats attenuated hypertension development by the lowering of sympathetic tone that is indeed elevated in L-NAME hypertensive rats (Pecháňová et al. 2004b). This is compatible with the recent findings on the importance of NO formation in the central nervous system, which is known to counteract stimulatory effects of central angiotensin II on the sympathetic tone (Osborn 2005, Dampney et al. 2005).

Sympathetic nerve system (enhanced by NO deficiency in the central nervous system) contributes to cardiovascular disorders in NO-deficient hypertension (Gerová et al. 1995). In L-NAME-treated animals in which rilmenidine (an agonist of imidazoline receptors) was administered, the elevation of systolic blood pressure was prevented and endothelium-dependent relaxation was improved. However, the NO synthase activity in aorta and left ventricle remained low in spite of rilmenidine administration (Gerová et al. 2004). This is in a good agreement with the major importance of SNS for blood pressure maintenance in L-NAME hypertensive rats, which was disclosed using a sequential blockade of principal vasoactive systems (Pecháňová et al. 2004b).

NO is hypothesized to be an inhibitory modulator of peripheral (Vo et al. 1991, Kyselá and Török 1997) and central sympathetic nervous outflow (Gerová et al. 1995). Deficient neuronal NO production is thought to cause sympathetic overactivity that contributes to NO-deficient arterial hypertension (Sander and Victor 1999). Short-term sympathectomy attenuated the L-NAME-induced hypertension, suggesting that increased central sympathetic drive may be involved in hypertension induced by chronic NO synthase inhibition. Sander and Victor (1999) suggested that the neurogenic component increases with time and that an intact adrenergic system is necessary for the full expression and maintenance of this type of hypertension. Available data appear to indicate that sympathetic overactivity follows NO inhibition and that the sympathetic nervous system plays a major role in the hypertension induced by chronic NO inhibition. In L-NAME-induced hypertension there is altered balance between the enhanced sympathetic vasoconstriction and the attenuated vasodilatation (due to missing NO and insufficiently up-regulated EDHF)
(Kuneš et al. 2004, Pechán̆ová et al. 2004b, Zicha et al. 2006a).

Various antioxidants and/or scavengers of oxygen free radicals have been reported to activate nitric oxide synthase and to increase the expression of NOS isoforms leading to blood pressure reduction and improvement of endothelial function (Kojšová et al. 2006). Red wine polyphenols have been reported to possess beneficial properties for preventing cardiovascular disorders including NO-deficient hypertension in rats (Bernátová et al. 2002, Pecháňová et al. 2004a, 2006, Jendeková et al. 2006). Red wine polyphenols prevented, at least in part, the elevation of blood pressure, aortic thickening and vascular dysfunction. These beneficial changes were associated with an increase of NO synthase activity and reduction of oxidative stress in the aorta and left ventricle (Pecháňová et al. 2004a). The imbalance between NO production and reactive oxygen species formation was also suggested to be an important factor in several other forms of hypertension.

Spironolactone, aldosterone receptor antagonist, improved NO production and partially prevented hypertension and hypertrophy of the left ventricle, but not of the aorta, in NO-deficient hypertension despite improving NO synthase activity in the heart and aorta (Šimko et al. 2007a,b). Similarly, simvastatin, 3-hydroxy-3-methylglutaryl coenzyme A (HMG-CoA) reductase inhibitor, was able to increase NOS activity with a simultaneous decrease of reactive oxygen species (ROS) concentration, which finally leads to the attenuation of hypertension and to the improvement of endothelium-dependent relaxation (Šimko et al. 2004, Török et al. 2007a).

Another open and rarely investigated topic concerns the mechanisms by which the reversion of already developed L-NAME hypertension and/or associated alterations is achieved. After the cessation of L-NAME treatment there is a complete (Bernátová et al. 2002) or partial (Bernátová et al. 2002, Paulis et al. 2008 b) spontaneous reduction of blood pressure together with a different degree of restoration of NO synthase activity, acetylcholine-induced relaxation and left ventricular hypertrophy, but no regression of left ventricular fibrosis was observed (Bernátová et al. 2000, Paulis et al. 2008b). The administration of captopril or provinol after the discontinuation of L-NAME treatment (Bernátová et al. 2000, 2002) enhanced the regression of hypertension and left ventricular fibrosis, while 
L-arginine and spironolactone had less effect on blood pressure or fibrosis (Šimko et al. 2007b) despite their effect on NO synthase activity. These data indicate that NO deficiency is important for the development of this type of hypertension, whereas other mechanisms are responsible for its maintenance and for the regression of structural alterations.

\section{Spontaneous hypertension}

The role of NO in spontaneously hypertensive rats (SHR) remains a subject to debate. Impaired (Lüscher and Vanhoutte 1991), unchanged (Török and Kristek 2001) or enhanced NO function (Chen and $\mathrm{Hu}$ 1997, Wu and Yen 1999) have been reported in SHR.

It has been shown that during the developmental phase of hypertension (prehypertensive and early hypertensive stage) in SHR, endothelium-dependent relaxation is preserved or possibly even enhanced so that a putative impairment of this function provides no significant pathogenic contribution to the onset of hypertension in this model (Radaelli et al. 1998, Török et al. 2006). Similarly, in the aorta of young stroke-prone SHR, the endothelium-dependent relaxation and the production of $\mathrm{NO}$ in response to cholinergic agonists were enhanced, compared to WKY rats (Onda et al. 1994), supporting the concept of enhancement of NO function at the onset of hypertensive state.

It should be noted that endothelium-dependent relaxation responses to acetylcholine were lower in aortic rings isolated from SHR aged 16-20 and 55-60 weeks as compared with those seen in age-matched normotensive rats. Aging induced a reduction of the relaxation response to acetylcholine in aortic rings from normotensive rats but not from SHR (Imaoka et al. 1999).

In adult SHR, Grunfeld et al. (1995) found that the production of $\mathrm{NO}$ in the heart and blood vessels is generally not affected and can even be increased, but the enhanced production of superoxide anion reduces its bioavailability. In this case NO is not able to stimulate sufficient amount of cGMP and to maintain an adequate NO-dependent vasodilatation (Nava et al. 1998).

In rats with borderline hypertension (born as F1 offspring of spontaneously hypertensive dams and normotensive Wistar sires) the impaired endotheliumdependent relaxation was not found. This has been supported by the finding that their aortic NO production was even elevated in comparison with normotensive rats (Bernátová et al. 2007a).
The impaired relaxation of aorta in adult SHR could be attributed either to enhanced endotheliumderived constricting factors production with no or little alteration in the production of $\mathrm{NO}$ and/or reduced bioavailability of NO. The release of cyclooxygenasederived contractile prostanoids, but not that of endothelin, is responsible for the impairment of endotheliumdependent relaxations (Lüscher and Vanhoutte 1991, Vanhoutte et al. 2005).

The elevation of blood pressure itself is probably not the cause of depressed acetylcholine-induced relaxation in phenylephrine-precontracted aorta. We have compared endothelial function in two different models of experimental hypertension - NO-deficient and spontaneous (Török and Kristek 2001). While in both groups of rats blood pressure was elevated, the endothelium-dependent relaxation in aorta to acetylcholine in NO-deficient rats was markedly inhibited and in SHR was preserved. It seems that increased blood pressure and accompanying structural changes are not primarily responsible for the impairment of endotheliumdependent relaxation in hypertension.

Chronic administration of $\mathrm{N}$-acetylcysteine (NAC), which is an antioxidant with thiol group, partially attenuated the blood pressure increase occurring in young SHR. Mechanisms responsible for blood pressure reduction appears to be related to both the decrease of ROS level and the increase of NO production (Pecháňová et al. 2006, 2007). In SHR with established hypertension NAC and melatonin improved the NO/ROS balance but blood pressure was reduced by melatonin only (Pecháňová et al. 2007).

It has been shown that treatment of young SHR with indapamide increased NOS activity in the aorta and improved acetylcholine-induced relaxation of the femoral artery (Kojšová et al. 2006).

Contrary to that what was found in NO-deficient hypertensive rats subjected to long-term administration of exogenous NO donors, in SHR neither PETN nor molsidomine evoked significant effects on blood pressure and heart weight/body weight ratio as well as on geometry of conduit arteries (inner diameter, arterial wall thickness, cross-sectional area) (Kristek 1998, Kristek et al. 2003). It seems that pathological changes in the cardiovascular system of SHR, in contrast to NOdeficient hypertension, are not evoked by NO deficiency.

Captopril, besides the inhibition of angiotensin converting enzyme, prevented hypertension by increasing NO synthase activity and by simultaneous decrease of 
oxidative stress, which contributed in young SHR to a complete prevention of hypertension development (Pecháňová 2007). However, the most important mechanism by which captopril lowers blood pressure of SHR is the reduction of sympathetic tone (Berecek et al. 1987, Paulis et al. 2007, Hojná et al. 2007).

The enhanced sympathetic activity partially counterbalanced by NO seems to be the major regulatory abnormality responsible for hypertension in SHR. It has been shown that NO counterbalances angiotensin II effects on sympathetic stimulation on the peripheral as well as central level (Campese et al. 2005, Paulis et al. 2007, Hojná et al. 2007). Thus elevated basal vascular NO synthesis in hypertensive rats may be an adapting mechanism, preventing them from excessive blood pressure elevation.

\section{Hypertension accompanying hereditary hypertriglyceridemia}

Hereditary hypertriglyceridemic (hHTG) rats were developed as a genetic model of human hypertriglyceridemia from the colony of Wistar rats (Vrána and Kazdová 1990). Hereditary hypertriglyceridemia in rats was found to be associated with several metabolic abnormalities (hyperinsulinemia, insulin resistance, hypertriglyceridemia) and mild elevation of blood pressure (Štolba et al. 1992, Klimeš et al. 1997).

It has been demonstrated that hHTG rats have impaired endothelium-dependent relaxation induced by acetylcholine in the aorta and iliac artery, which is accompanied by marked changes in vascular architecture (Kristek et al. 1997, Török et al. 2002, 2007a, Čačányiová et al. 2006).

In early stage of hypertension in hHTG rats the endothelium-dependent relaxation is not impaired (Török et al. 2006). However, contractile response of aorta to noradrenaline was smaller than in age-matched control Wistar rats. At the same time morphological study showed that the wall thickness of thoracic aorta of young hHTG rats was thinner than that of control thoracic aorta (Török et al. 2006). Similar morphological changes were observed by Cebová et al. (2006) who studied structural alterations in carotid artery of 3-week-old hHTG rats. While blood pressure in young hHTG rats was significantly higher than in age-matched Wistar rats, the wall thickness of the carotid artery was thinner in comparison with Wistar rats. But later blood pressure increased with ageing and hypertrophy of arterial wall in 52-week-old hHTG rats was observed (Cebová et al. 2006). It is suggested that blood pressure is probably not the main cause of morphological changes during ontogenetic development in hHTG rats.

There is no general agreement on the mechanisms that may be responsible for the impairment of endothelium-dependent relaxation (vascular dilatation) in adult and/or aged hHTG rats. The role of elevated plasma triglycerides cannot be excluded because impaired endothelial function has been found within several hours after triglyceride load in both animals and humans (Bae et al. 2001, Gudmundsson et al. 2000).

The increase of blood pressure represents a hemodynamic overload in hHTG rats that induces left ventricular hypertrophy (Šimko et al. 2005). This model of hypertension is not associated with ventricular fibrosis. Chronic treatment of hHTG rats with ACE inhibitor captopril eliminated both hypertension and left ventricle hypertrophy (Šimko et al. 2005).

It has been demonstrated that increased formation of angiotensin II is an important factor in the progression of endothelial dysfunction in hereditary hypertriglyceridemic rats. Pharmacological blockade of angiotensin II formation by captopril has been shown to improve endothelial dysfunction and to retard the progression of blood pressure elevation not only in SHR (Rodrigo et al. 1997) but also in hHTG rats. We have shown that chronic treatment of hHTG rats with captopril reduced elevated blood pressure, prevented impairment of endothelium-dependent relaxation in aorta, and reduced heart and aortic remodeling in hHTG rats (Šimko et al. 2002, Török et al. 2002, 2006, Zicha et al. 2006b). The above findings suggest that NO production has been improved by captopril treatment.

Hereditary hypertriglyceridemic rats responded to acute injection of tetraethylammonium (inhibitor of calcium-dependent $\mathrm{K}^{+}$channels opened by EDHF) by marked elevation of blood pressure, which suggests a considerable participation of EDHF in vasodilator mechanisms in hHTG rats (Zicha et al. 2006b).

Several authors have reported that NO-deficient hypertension is associated with hyperlipidemia, hyperinsulinemia and insulin resistance. This is supported by the finding of Cook et al. (2004) that mice with targeted disruption of eNOS were hypertensive and insulin-resistant and showed fasting hyperinsulinemia and increased plasma concentration of cholesterol, triglycerides, and free fatty acids. It means that NO 
deficiency besides increasing blood pressure also affects glucose and lipid homeostasis, mimicking the human metabolic syndrome X. Therefore, NO deficiency could create a link between metabolic and cardiovascular diseases.

\section{The role of NO in hypertension elicited by chronic social stress}

Chronic social stress is risk factor in the etiology of civilization diseases including hypertension. Hypertensive patients have increased basal sympathetic activity and greater sympathetic reactivity in response to mental stress (Kaushik et al. 2004). Social stress is supposed to be connected to the changes in bioavailability of NO (Malyshev and Manukhina 1998, Bernátová et al. 2007a), which can be manifested by various abnormalities including alteration of vascular reactivity.

Chronic crowding stress in normotensive Wistar rats (rats kept in markedly reduced living space) caused an increase response to acetylcholine and a decrease in the reactivity of blood vessels to noradrenaline (Cordellini and Vassilieff 1998, Púzserová et al. 2006, Bernátová et al. 2007a). These responses, e.g. improved relaxation to acetylcholine as well as hyporeactivity to noradrenaline, were observed in both acute and chronic induced stress. It means that crowded normotensive rats were able to modify their vascular function in order to maintain blood pressure at normal level. L-NAME administration and endothelium removal abolished the stress-induced aorta hyporeactivity (Cordellini et al. 2006).

On the other side, in rats with borderline hypertension (offspring of the spontaneously hypertensive dams) crowding increased blood pressure and reduced aortic NO synthase activity. Acetylcholineinduced relaxation was unaltered (Bernátová et al. 2007a). These results suggest that borderline hypertensive rats were unable of effective adaptation of vascular function in stressful conditions resulting in greater augmentation of blood pressure.

In chronic crowding stress the magnitude of neurogenic responses induced by endogenous noradrenaline (NA) was reduced in mesenteric artery from stressed SHR. In rats simultaneously exposed to crowding stress and L-NAME, inhibitor of NO synthase, the decreased activity of mesenteric artery to endogenous noradrenaline was restored (Török et al. 2007b), suggesting that hyporeactivity is due to an increase in the NO system activity. These results suggest that decreased activity of sympathetic nervous system in arterial system may contribute to the protective mechanisms in hypertensive animals exposed to chronic social stress.

\section{Salt-dependent hypertension}

Previous studies have indicated that inhibition of NO generation during high-salt intake leads to the development of salt-sensitive hypertension and the impairment of endothelium-dependent relaxation (Lüscher et al. 1987, Nakanishi et al. 2002). Thus, the increase in superoxide level causing NO deficiency may significantly contribute to the development of saltsensitive forms of hypertension. Antihypertensive pharmacological therapy normalized altered endotheliumdependent relaxation and prevented the development of hypertension in Dahl salt-sensitive rats kept on a high-salt diet (Lüscher et al. 1987).

Imbalance between the production of $\mathrm{NO}$ and superoxide in the kidney primarily determines the conditions of oxidative stress that alters renal hemodynamics and excretory function leading to sodium retention and, thus, contributes to the development of salt-sensitive hypertension (Majid and Kopkan 2007).

The sympathetic nervous system exerts the most important contribution in salt hypertension maintenance, whereas the role of angiotensin II in blood pressure maintenance is almost negligible (Kuneš et al. 2004). The NO system is not able to counterbalance effectively the hyperactivity of the sympathetic nervous system in salthypertensive Dahl rats. The predominance of sympathetic vasoconstriction over NO-dependent vasodilatation could be explained partially by enhanced NO inactivation due to augmented superoxide anion formation in hypertensive animals (Zicha et al. 2001). The impairment of NOdependent vasodilatation in young salt hypertensive rats was due to enhanced NO inactivation by augmented superoxide formation rather than due to a defective NO synthesis (Zicha et al. 2001).

\section{Conclusions}

Nitric oxide has important role in different physiological processes, such as regulation of blood pressure and vasomotor tone, platelet-endothelium interaction, control of cell proliferation, neurotransmission and immunomodulation. Dysfunction 
in the formation of NO and/or increased NO metabolism takes part in pathogenesis of hypertension and other cardiovascular disorders.

The imbalance between the vasoconstricting and vasorelaxing factors is a common feature in several models of hypertension. These models may differ in the factor, which plays the most important role in the development of particular form of experimental hypertension. NO-deficiency is the principal factor responsible for the development of L-NAME-induced hypertension, but several other factors (including RAAS, production of constrictor factors, arterial remodeling and increased activity of sympathetic nervous system) also seem to be involved. In spontaneously hypertensive rats the sympathetic overactivity might play the key role in hypertension, while NO production might be unchanged or even enhanced in order to compensate the increase in blood pressure. In the model of hHTG rats, characterized by a mild hypertension, the endothelial damage is also associated with impaired endothelium-dependent relaxations, possibly due to reduced NO formation. The enhanced activity of the sympathetic nervous system seems to be a principal factor in the development of stress-induced hypertension, where the endotheliumdependent relaxations might be unchanged or even enhanced.

Administration of antioxidants and other compounds with antioxidant properties to hypertensive animals reduced blood pressure, reversed the changes in vascular reactivity and reduced thickness of arterial wall, increased production of nitric oxide and/or improved its bioavailability. Antioxidant activity of antihypertensive drugs may also significantly contribute to their beneficial effects, i.e. blood pressure reduction and prevention of target organ damage.

Further research should be focused on complete elucidation of the interactive role of $\mathrm{NO}$ and reactive oxygen species in the regulation of many organ functions to increase our knowledge on physiology as well as pathophysiological processes of many diseases, including cardiovascular diseases that are linked to NO metabolism and oxidative stress. A special attention should be paid to the role of nitric oxide in the central nervous mechanisms governing cardiovascular homeostasis.

\section{Conflict of Interest}

There is no conflict of interest.

\section{Acknowledgements}

Supported by grant VEGA No.2/6150/28.

\section{References}

AHLNER J, ANDERSSON RG, TORFGARD K, AXELSSON KL: Organic nitrate esters: clinical use and mechanisms of actions. Pharmacol Rev 43: 351-423, 1991.

ARNAL JF, YAMIN J, DOCKERY S, HARRISON DG: Regulation of endothelial nitric oxide synthase mRNA, protein, and activity during cell growth. Am J Physiol 267: C1381-C1388, 1994.

BABÁL P, PECHÁŇOVÁ O, BERNÁTOVÁ I, ŠTVRTINA S: Chronic inhibition of NO synthesis produces myocardial and arterial media hyperplasia. Histol Histopathol 12: 623-629, 1997.

BAE JH, BASSENGE E, KIM KB, KIM YN, KIM KS, LEE HJ, MOON KC, LEE MS, PARK KY, SCHWEMMER M: Postprandial hypertriglyceridemia impairs endothelial function by enhanced oxidant stress. Atherosclerosis 155: 517-523, 2001.

BERECEK KH, KIRK KA, NAGAHAMA S, OPARIL S: Sympathetic function in spontaneously hypertensive rats after chronic administration of captopril. Am J Physiol 252: H796-H806, 1987.

BERNÁTOVÁ I, PECHÁŇOVÁ O, KRISTEK F: Mechanism of structural remodeling of the aorta during long-term L-NAME treatment. Jpn J Pharmacol 81: 99-106, 1999a.

BERNÁTOVÁ I, PECHÁŇOVÁ O, ŠIMKO F: Effect of captopril in L-NAME-induced hypertension on the rat myocardium, aorta, brain and kidney. Exp Physiol 84: 1095-1105, 1999 b.

BERNÁTOVÁ I, PECHÁŇOVÁ O, PELOUCH V, ŠIMKO F: Regression of chronic L-NAME-treatment-induced left ventricular hypertrophy: effect of captopril. J Mol Cell Cardiol 32: 177-185, 2000.

BERNÁTOVÁ I, PECHÁŇOVÁ O, BABÁL P, KYSELÁ S, ŠTVRTINA S, ANDRIANTSITOHAINA R: Wine polyphenols improve cardiovascular remodeling and vascular function in NO-deficient hypertension. $\mathrm{Am} J$ Physiol 282: H942-H948, 2002. 
BERNÁTOVÁ I, CSIZMÁDIOVÁ Z, KOPINCOVÁ J, PÚZSEROVÁ A: Vascular function and nitric oxide production in chronic social stress-exposed rats with various family history of hypertension. $J$ Physiol Pharmacol 58: 487-501, 2007a.

BERNÁTOVÁ I, KOPINCOVÁ J, PÚZSEROVÁ A, JANEGA P, BABÁL P: Chronic low-dose L-NAME treatment increases nitric oxide production and vasorelaxation in normotensive rats. Physiol Res 56 (Suppl 2): S17-S24, $2007 \mathrm{~b}$

BUSSE R, FLEMING I: Vascular endothelium and blood flow. Handb Exp Pharmacol 176 (Pt 2): 43-78, 2006.

CAMPESE VM, SHAOHUA Y, HUIQUIN Z: Oxidative stress mediates angiotensin II-dependent stimulation of sympathetic nerve activity. Hypertension 46: 533-539, 2005.

CEBOVÁ M, KRISTEK F, KUNEŠ J: Differential remodeling of carotid artery in spontaneously hypertensive and hereditary hypertensive rats. Physiol Res 55 (Suppl 1): S81-S87, 2006.

CHEN HI, HU CT: Endogenous nitric oxide on arterial hemodynamics: a comparison between normotensive and hypertensive rats. Am J Physiol 273: H1816-H1823, 1997.

COOK S, HUGLI O, EGLI M, MÉNARD B, THALMANN S, SARTORI C, PERRIN C, NICOD P, THORENS B, VOLLENWEIDER P, SCHERRER U, BURCELIN R: Partial gene deletion of endothelial nitric oxide synthase predisposes to exaggerated high-fat diet-induced insulin resistance and arterial hypertension. Diabetes 53: 2067-2072, 2004.

CORDELLINI S, VASSILIEFF VS: Decreased endothelium-dependent vasoconstriction to noradrenaline in acutestressed rats is potentiated by previous chronic stress: nitric oxide involvement. Gen Pharmacol 30: 79-83, 1998.

CORDELLINI S, NOVO R, JÚNIOR UL: Exposure to stress. Differential vascular adaptive response in spontaneously hypertensive and Wistar rats: Role of nitric oxide, and prehypertensive and hypertensive states. Life Sci 79: 646-653, 2006.

ČAČÁNYIOVÁ S, CEBOVÁ M, KUNEŠ J, KRISTEK F: Comparison of vascular function and structure of iliac artery in spontaneously hypertensive and hereditary hypertriglyceridemic rats. Physiol Res 55 (Suppl 1): S73-S80, 2006.

DAMPNEY RA, HORIUCHI J, KILLINGER S, SHERIFF MJ, TAN PS, MCDOWALL LM: Long-term regulation of arterial blood pressure by hypothalamic nuclei: some critical questions. Clin Exp Pharmacol Physiol 32: 419-425, 2005.

FÉLÉTOU M, VANHOUTTE PM: Endothelial dysfunction: a multifaceted disorder. Am J Physiol 291: H985-H1002, 2006.

FURCHGOTT RF, ZAWADZKI JV: The obligatory role of endothelial cells in the relaxation of arterial smooth muscle by acetylcholine. Nature 288: 373-376, 1980.

GARDINER SM, COMPTON AM, BENNETT T, PALMER RMJ, MONCADA S: Regional hemodynamic changes during oral ingestion of $\mathrm{N}^{\mathrm{G}}$-monomethyl-L-arginine or $\mathrm{N}^{\mathrm{G}}$-nitro-L-arginine methyl ester in conscious Brattleboro rats. Br J Pharmacol 101: 10-12, 1990.

GEROVÁ M, MAŠANOVÁ C, PAVLÁSEK J: Inhibition of NO synthase in the posterior hypothalamus increases blood pressure in the rat. Physiol Res 44: 131-134, 1995.

GEROVÁ M, TÖRÖK J, PECHÁŇOVÁ O, MATÚŠKOVÁ J: Rilmenidine prevents blood pressure increase in rats with compromised nitric oxide production. Acta Pharmacol Sin 25: 1640-1646, 2004.

GRUNFELD S, HAMILTON CA, MESAROS S, MCLAIN SW, DOMINICZAK AF, BOHR DF, MALINSKI T: Role of superoxide in the depressed nitric oxide production by the endothelium of genetically hypertensive rats. Hypertension 26: 854-857, 1995.

GUDMUNDSSON GS, SINKEY CA, CHENARD CA, STUMBO PJ, HAYNES WG: Resistance vessel endothelial function in healthy humans during transient postprandial hypertriglyceridemia. Am J Cardiol 85: 381-385, 2000.

HOJNÁ S, KADLECOVÁ M, DOBEŠOVÁ Z, VALOUŠKOVÁ V, ZICHA J, KUNEŠ J: The participation of brain NO synthase in blood pressure control of adult spontaneously hypertensive rats. Mol Cell Biochem 297: 21-29, 2007. 
HOLÉCYOVÁ A, TÖRÖK J, BERNÁTOVÁ I, PECHÁŇOVÁ O: Restriction of nitric oxide rather than elevated blood pressure is responsible for alterations of vascular responses in nitric oxide-deficient hypertension. Physiol Res 45: 317-321, 1996.

HSIEH NK, WANG JY, LIU JC, WANG SD, CHEN HI: Nitric oxide inhibition accelerates hypertension and induces perivascular inflammation in rats. Clin Exp Pharmacol Physiol 31: 212-218, 2004.

IMAOKA Y, OSANAI T, KAMADA T, MIO Y, SATOH K, OKUMURA K: Nitric oxide-dependent vasodilator mechanism is not impaired by hypertension but is diminished with aging in the rat aorta. $J$ Cardiovasc Pharmacol 33: 756-761, 1999.

JENDEKOVÁ L, KOJŠOVÁ S, ANDRIANTSITOHAINA R, PECHÁŇOVÁ O: The time-dependent effect of Provinols $^{\mathrm{TM}}$ on brain NO synthase activity in L-NAME-induced hypertension. Physiol Res 55 (Suppl 1): S31S37, 2006.

KAUSHIK RM, MAHAJAN SK, RAJESH V, KAUSHIK R: Stress profile in essential hypertension. Hypertens Res 27: 619-624, 2004.

KLIMEŠ I, ZICHA J, KUNEŠ J, ŠEBŐKOVÁ E: Hypertriglyceridemia, insulin resistance and hypertension in rats: are they related? Endocr Regul 31: 103-119, 1997.

KOJŠOVÁ S, JENDEKOVÁ L, ZICHA J, KUNEŠ J, ANDRIANTSITOHAINA R, PECHÁŇOVÁ O: The effect of different antioxidants on nitric oxide production in hypertensive rats. Physiol Res 55 (Suppl 1): S3-S16, 2006.

KRISTEK F: Long-term administration of L-arginine did not influence blood pressure, heart rate, cardiac hypertrophy or arterial wall thickness of spontaneously hypertensive rats. Exp Physiol 83: 595-603, 1998.

KRISTEK F: Pentaerythrityl tetranitrate could prevent structural changes in conduit arteries evoked by long-term NOsynthase inhibition. Br J Pharmacol 130: 450-456, 2000.

KRISTEK F, GEROVÁ M: Remodelling of septal branch of coronary artery and carotid artery in L-NAME treated rats. Physiol Res 45: 329-333, 1996a.

KRISTEK F, GEROVÁ M: Long-term NO synthase inhibition affects heart weight and geometry of coronary and carotid arteries. Physiol Res 45: 361-367, 1996 b.

KRISTEK F, GEROVÁ M: Hypotrophy of conduit artery wall in offspring of NO defective rats. Braz J Med Biol Res 37: 601-606, 2004.

KRISTEK F, EDELSTEINOVÁ S, ŠEBÖKOVÁ E, KYSELOVIČ J, KLIMEŠ I: Structural changes in the aorta of the hereditary hypertriglyceridemic rat. Ann N Y Acad Sci 827: 514-520, 1997.

KRISTEK F, FÁBEROVÁ V, VARGA I: Long-term effect of molsidomine and pentaerythrityl tetranitrate on cardiovascular system of spontaneously hypertensive rats. Physiol Res 52: 709-717, 2003.

KUNEŠ J, HOJNÁ S, KADLECOVÁ M, DOBEŠOVÁ Z, RAUCHOVÁ H, VOKURKOVÁ M, LOUKOTOVÁ J, PECHÁŇOVÁ O, ZICHA J: Altered balance of vasoactive systems in experimental hypertension: the role of relative NO deficiency. Physiol Res 53 (Suppl 1): S23-34, 2004.

KYSELÁ S, TÖRÖK J: Role of endothelial nitric oxide in neurogenic contractions of rabbit carotid artery during cooling. (in Slovak) Bratisl Lek Listy 98: 80-85, 1997.

LINCOLN J, BURNSTOCK G: Neural-endothelial interactions in control of local blood flow. In: The Endothelium: An Introduction to Current Research, J WARREN (ed), Wiley-Liss, New York, 1990, pp 21-31.

LÜSCHER TF, VANHOUTTE PM: The Endothelium: Modulator of Cardiovascular Functions. CRC Press, Boca Raton, 1991, pp 1-228.

LÜSCHER TF, VANHOUTTE PM, RAIJ L: Antihypertensive treatment normalizes decreased endothelium-dependent relaxations in rats with salt-induced hypertension. Hypertension 9 (Suppl III): III193-III97, 1987.

MAJID DSA, KOPKAN L: Nitric oxide and superoxide interactions in the kidney and their implication in the development of salt-sensitive hypertension. Clin Exp Pharmacol Physiol 34: 946-952, 2007.

MALYSHEV IY, MANUKHINA EB: Stress adaptation and nitric oxide. Biochemistry (Mosc) 63: 840-853, 1998.

MONCADA S: Nitric oxide gas: mediator, modulator, and pathophysiologic entity. J Lab Clin Med 120: 187-191, 1992.

NAKANISHI K, HARA N, NAGAI Y: Salt-sensitive hypertension in conscious rats induced by chronic nitric oxide blockade. Am J Hypertens 15: 150-156, 2002. 
NAVA E, FARRE AL, MORENO C, CASADO S, MOREAU P, COSENTINO F, LÜSCHER TF: Alterations to the nitric oxide pathway in the spontaneously hypertensive rat. J Hypertens 16: 609-615, 1998.

ONDA T, MASHIKO S, HAMAMO M, TOMITA I, TOMITA T: Enhancement of endothelium-dependent relaxation in the aorta from stroke-prone spontaneously hypertensive rats at developmental stages of hypertension. Clin Exp Pharmacol Physiol 11: 857-863, 1994.

OSBORN JW: Hypothesis: set-points and long-term control of arterial pressure. A theoretical argument for a long-term arterial pressure control system in the brain rather than the kidney. Clin Exp Pharmacol Physiol 32: 384-393, 2005.

PATEL KP, LI YF, HIROOKA Y: Role of nitric oxide in central sympathetic outflow. Exp Biol Med (Maywood) 226: 814-824, 2001.

PAULIS L, LÍŠKOVÁ S, PINTÉROVÁ M, DOBEŠOVÁ Z, KUNEŠ J, ZICHA J: Nifedipine-sensitive noradrenergic vasoconstriction is enhanced in spontaneously hypertensive rats: the influence of chronic captopril treatment. Acta Physiol (Oxford) 191: 255-266, 2007.

PAULIS L, ZICHA J, KUNEŠ J, HOJNÁ S, BEHULIAK M, CELEC P, KOJŠOVÁ S, PECHÁŇOVÁ O, ŠIMKO F: Regression of L-NAME-induced hypertension: the role of nitric oxide and endothelium-derived constricting factor. Hypertens Res 31: 793-803, 2008a.

PAULIS L, MATÚŠKOVÁ J, ADAMCOVÁ M, PELOUCH V, ŠIMKO J, KRAJČIROVIČOVÁ K, POTÁČOVÁ A, GVOZDJÁKOVÁ A, HULÍN I, JANEGA P, PECHÁŇOVÁ O, ŠIMKO F: Regression of left ventricular hypertrophy and aortic remodeling in NO-deficient hypertensive rats: effect of L-arginine and spironolactone. Acta Physiol (Oxf) 194: 45-55, 2008 b.

PECHÁŇOVÁ O: Contribution of captopril thiol group to the prevention of spontaneous hypertension. Physiol Res 56 (Suppl 2): S41-S48, 2007.

PECHÁŇOVÁ O, BERNÁTOVÁ I, PELOUCH V, ŠIMKO F: Protein remodelling of the heart in NO-deficient hypertension: the effect of captopril. J Mol Cell Cardiol 29: 3365-3374, 1997.

PECHÁŇOVÁ O, BERNÁTOVÁ I, PELOUCH V, BABÁL P: L-NAME-induced protein remodeling and fibrosis in the rat heart. Physiol Res 48: 353-362, 1999.

PECHÁŇOVÁ O, BERNÁTOVÁ I, BABÁL $\mathrm{P}$, MARTINEZ MC, KYSELÁ S, ŠTVRTINA S, ANDRIANSITOHAINA R: Red wine polyphenols prevent cardiovascular alterations in L-NAME-induced hypertension. J Hypertens 22: 1551-1559, 2004a.

PECHÁŇOVÁ O, DOBEŠOVÁ Z, ČEJKA J, KUNEŠ J, ZICHA J: Vasoactive systems in L-NAME hypertension: the role of inducible NO synthase. J Hypertens 22: 167-173, 2004b.

PECHÁŇOVÁ O, REZZANI R, BABÁL P, BERNÁTOVÁ I, ANDRIANTSITOHAINA R: Beneficial effects of Provinols $^{\mathrm{TM}}$ : cardiovascular system and kidney. Physiol Res 55 (Suppl 1): S17-S30, 2006.

PECHÁŇOVÁ O, ZICHA J, PAULIS L, ZENEBE W, DOBEŠOVÁ Z, KOJŠOVÁ S, JENDEKOVÁ L, SLÁDKOVÁ M, DOVINOVÁ I, ŠIMKO F, KUNEŠ J: The effect of N-acetylcysteine and melatonin in adult spontaneously hypertensive rats with established hypertension. Eur J Pharmacol 561: 129-136, 2007.

PECHÁŇOVÁ O, KOJŠOVÁ S, JENDEKOVÁ L: Ambivalent effect of chronic L-NAME treatment in the heart and brain: the role of nuclear factor-кB. J Hypertens 26 (Suppl 1): S85, 2008.

PÚZSEROVÁ A, CSIZMADIOVÁ Z, ANDRIANTSITOHAINA R, BERNÁTOVÁ I: Vascular effect of red wine polyphenols in chronic stress-exposed Wistar-Kyoto rats. Physiol Res 55 (Suppl 1): S39-S47, 2006.

RADAELLI A, MIRCOLI L, MORI I, MANCIA G, FERRARI AU: Nitric oxide dependent vasodilation in young spontaneously hypertensive rats. Hypertension 32: 735-739, 1998.

RIBEIRO MO, ANTUNES E, DE NUCCI G, LOVISOLO SM, ZATZ R: Chronic inhibition of nitric oxide synthesis. A new model of arterial hypertension. Hypertension 20: 298-303, 1992.

RODRIGO E, MAESO R, MUNOZ-GARCIA R, NAVARRO-CID J, RUILOPE LM, CACHOFEIRO V, LAHERA V: Endothelial dysfunction in spontaneously hypertensive rats: consequences of chronic treatment with losartan or captopril. J Hypertens 15: 613-618, 1997.

ROMERO JC, RECKELHOFF JF: Role of angiotensin and oxidative stress in essential hypertension. Hypertension 34: 943-949, 1999.

ROSS R: Atherosclerosis: an inflammatory disease. N Engl J Med 340: 115-126, 1999. 
SANDER M, VICTOR RG: Neural mechanisms in nitric-oxide-deficient hypertension. Curr Opin Nephrol Hypertens 8: 61-73, 1999.

SMIEŠKO V, JOHNSON PC: The arterial lumen is controlled by flow-related shear stress. News Physiol Sci 8: 34-38, 1993.

SMIEŠKO V, KOŽÍK J, DOLEŽEL S: Role of endothelium in the control of arterial diameter by blood flow. Blood Vessels 22: 247-251, 1985.

ŠIMKO F, LUUPTÁK I, MATÚŠKOVÁ J, BABÁL P, PECHÁŇOVÁ O, BERNÁTOVÁ I, HULÍN I: Heart remodeling in the hereditary hypertriglyceridemic rat: effect of captopril and nitric oxide deficiency. Ann N Y Acad Sci 967: 454-462, 2002.

ŠIMKO F, MATÚŠKOVÁ J, L'UPTÁK I, KRAJČIROVIČOVÁ K, KUCHARSKÁ J, GVOZDJÁKOVÁ A, BABÁL P, PECHÁŇOVÁ O: Effect of simvastatin on remodeling of the left ventricle and aorta in L-NAME-induced hypertension. Life Sci 74: 1211-1224, 2004.

ŠIMKO F, PELOUCH V, TÖRÖK J, LUUPTÁK I, MATÚŠKOVÁ J, PECHÁŇOVÁ O, BABÁL P: Protein remodeling of the heart ventricles in hereditary hypertriglyceridemic rat: effect of ACE-inhibition. J Biomed Sci 12: 103$111,2005$.

ŠIMKO F, MATÚŠKOVÁ J, LUUPTÁK I, PINČÍKOVÁ T, KRAJČIROVIČOVÁ K, ŠTVRTINA S, POMŠÁR J, PELOUCH V, PAULIS L, PECHÁŇOVÁ O: Spironolactone differently influences remodeling of the left ventricle and aorta in L-NAME-induced hypertension. Physiol Res 56 (Suppl 2): S25-S32, 2007a.

ŠIMKO F, POTÁČOVÁ A, PELOUCH V, PAULIS L', MATÚŠKOVÁ J, KRAJČIROVIČOVÁ K, PECHÁŇOVÁ O, ADAMCOVÁ M: Spontaneous, L-arginine-induced and spironolactone-induced regression of protein remodeling of the left ventricle in L-NAME-induced hypertension. Physiol Res 56 (Suppl 2): S55-S62, 2007b.

ŠTOLBA P, DOBEŠOVÁ Z, HUŠEK P, OPLTOVÁ H, ZICHA J, VRÁNA A, KUNEŠ J: The hypertriglyceridemic rat as a genetic model of hypertension and diabetes. Life Sci 51: 733-740, 1992.

TAKEMOTO M, EGASHIRA K, USUI M, NUMAGUCHI K, TOMITA H, TSUTSUI H, SHIMOKAWA H, SUEISHI $\mathrm{K}$, TAKESHITA A: Important role of tissue angiotensin-converting enzyme activity in the pathogenesis of coronary vascular and myocardial structural changes induced by long-term blockade of nitric oxide synthesis in rats. J Clin Invest 99: 278-287, 1997.

TÖRÖK J, GEROVÁ M: Vascular responses after long-term inhibition of nitric oxide synthesis in newborn dogs. Physiol Res 45: 323-328, 1996.

TÖRÖK J, GEROVÁ M: Developmental dynamics of endothelial and neurogenic control of canine thoracic aorta. Mech Ageing Dev 95: 143-152, 1997.

TÖRÖK J, KRISTEK F: Functional and morphological pattern of vascular responses in two models of experimental hypertension. Exp Clin Cardiol 6: 142-148, 2001.

TÖRÖK J, KRISTEK F: Beneficial effect of pentaerythrityl tetranitrate on functional and morphological changes in the rat thoracic aorta evoked by long-term nitric oxide synthase inhibition. Vascul Pharmacol 38: 177-182, 2002.

TÖRÖK J, HOLÉCYOVÁ A, KYSELÁ S, BERNÁTOVÁ I, PECHÁŇOVÁ O: Changes in reactivity of pulmonary and systemic arteries in chronic NO-deficient hypertension. (in Slovak) Kardiológia 7: 30-36, 1998.

TÖRÖK J, BABÁL P, MATÚŠKOVÁ J, LUPTÁK I, KLIMEŠ I, ŠIMKO F: Impaired endothelial function of thoracic aorta in the hereditary hypertriglyceridemic rats. Ann NY Acad Sci 967: 469-475, 2002.

TÖRÖK J, KOPRDOVÁ R, CEBOVÁ M, KUNEŠ J, KRISTEK F: Functional and structural pattern of arterial responses in hereditary hypertriglyceridemic and spontaneously hypertensive rats in early stage of experimental hypertension. Physiol Res 55 (Suppl 1): S65-S71, 2006.

TÖRÖK J, LUPTÁK I, MATÚŠKOVÁ J, PECHÁŇOVÁ O, ŠIMKO F: Comparison of the effect of simvastatin, spironolactone and L-arginine on endothelial function of aorta in hereditary hypertriglyceridemic rats. Physiol Res 56: S33-S40, 2007a.

TÖRÖK J, PÚZSEROVÁ A, ZEMANČÍKOVÁ A, BERNÁTOVÁ I: Effect of crowding stress on neurogenic contractions of the mesenteric artery in spontaneously hypertensive rats. In Proceedings of Genetic and Environmental Factors in Hypertension 2007, Bratislava2007b, pp 53-58.

TSENG CJ, LIU HY, LIN HC, GER LP, TUNG CS, YEN MH: Cardiovascular effects of nitric oxide in the brain stem nuclei of rats. Hypertension 27: 36-42, 1996. 
VANHOUTTE PM, FÉLÉTOU M, TADDEI S: Endothelium-dependent contraction in hypertension. Br J Pharmacol 144: 449-458, 2005.

VO PA, REID JJ, RAND MJ: Endothelial nitric oxide attenuates vasoconstrictor responses to nerve stimulation and noradrenaline in the rat tail artery. Eur J Pharmacol 199: 123-125, 1991.

VRÁNA A, KAZDOVÁ L: The hereditary hypertriglyceridemic nonobese rats: an experimental model of human hypertriglyceridemia. Transpl Proc 22: 2579, 1990.

WU CC, YEN MH: Higher level of plasma nitric oxide in spontaneously hypertensive rats. Am J Hypertens 12: 476$482,1999$.

ZICHA J, DOBEŠOVÁ Z, KUNEŠ J: Relative deficiency of nitric oxide-dependent vasodilation in salt-hypertensive Dahl rats: the possible role of superoxide anions. J Hypertens 19: 247-254, 2001.

ZICHA J, DOBEŠOVÁ Z, KUNEŠ J: Antihypertensive mechanisms of chronic captopril or N-acetylcysteine treatment in L-NAME hypertensive rats. Hypertens Res 29: 1021-1027, 2006a.

ZICHA J, PECHÁŇOVÁ O, ČAČÁNYIOVÁ S, CEBOVÁ M, KRISTEK F, TÖRÖK J, ŠIMKO F, DOBEŠOVÁ Z, KUNEŠ J: Hereditary hypertriglyceridemic rat: a suitable model of cardiovascular disease and metabolic syndrome? Physiol Res 55 (Suppl 1): S49-S63, $2006 \mathrm{~b}$. 